\title{
Mercado de Trabalho em Cirurgia Plástica. Academia versus Consultório Particular
}

\author{
Nivaldo Alonso
}

Um tema como este a 30 anos atrás seria taxado como mercantilização da nobre profissão médica. Medicina é um sacerdócio, Para se fazer medicina é preciso ter vocação, estas eram as frases mais comumente citadas por meus mestres na Escola Paulista de Medicina na década de 70. Hoje, porém a situação é outra, a decisão da escolha da especialidade médica, por vezes recai sobre a mais rentável ou mesmo por falta de médicos em determinada especialidade. A Cirurgia Plástica é hoje, uma especialidade muito procurada, por vários motivos, sendo sem sombra de dúvidas, o lado financeiro um dos mais relevantes. As características da especialidade, desvinculada de planos de saúde no que tange a cirurgia estética, e também, um apelo comercial muito vinculado à mídia moderna se destacam entre estes fatores. A grande abrangência de tratamento das deformidades que atingem todo o corpo humano e a grande interface com outras áreas médicas faz da Cirurgia Plástica, uma especialidade em grande ascensão no mercado de trabalho atual. O grande exemplo, hoje é a íntima relação entre o tratamento cirúrgico e a restauração, associados em um único tempo operatório. Reconstruções de mama e mastectomia associadas em um único tempo cirúrgico e as grandes reconstruções de tumores faciais associadas a reconstruções com retalhos compostos transferidos com o auxílio da microcirurgia são situações bastante comuns hoje no dia a dia do cirurgião plástico.

A formação básica muito longa se apresenta como um dos fatores, por vezes limitante. Um bom cirurgião plástico tem, hoje obrigatoriamente, necessidade de dois anos de formação em Cirurgia Geral e depois três anos em Cirurgia Plástica. Sendo que áreas como Craniofacial (leia-se tratamento de Deformidades Congênitas, Cirurgia Ortognática e Traumatismo Facial) e Microcirurgia, necessitam de no mínimo, mais um ano extra de treinamento específico. Aqueles que decidem seguir a carreira universitária têm ainda uma longa jornada pela frente. A carreira universitária é pautada pela necessidade de atuação não só na área assistencial, mas também na área de ensino. Os grandes pilares da carreira universitária são baseados na Assistência, Educação Médica Continuada, Pesquisa e mais recentemente a Gestão Financeira. Hoje a busca de recursos financeiros para complementar o ensino básico e a pesquisa é fundamental, caracterizando a gestão como ponto essencial neste quadrilátero acadêmico. A remuneração, muitas vezes não pode ser comparada ao que pode obtido no Mercado privado da Cirurgia Plástica. Entretanto o Mercado privado tem se mostrado cada vez mais exigente e competitivo. Com grande número de profissionais competentes no mercado, invasão de operadoras de Cirurgia Plástica que cirurgias em prestações e o número limitado de hospitais nas grandes metrópoles obrigam hoje os cirurgiões mais jovens a busca de novos horizontes em outros centros menores. Os números ainda reduzidos de cirurgia plástica reparadora quando comparados com o de cirurgias cosméticas são muito alentadores para os mais jovens. Como também a necessidade de descentralização dos

Professor Associado da Disciplina de Cirurgia Plástica da Faculdade de Medicina da USP. 
centros de tratamentos especializados em grandes queimados e deformidades congênitas como fissuras lábio palatinas, para áreas mais longínquas do país, faz com que o deslocamento de jovens, cirurgiões plásticos bem formados e altamente especializados sejam muito bem vindos em quase todas as regiões do nosso país. Da mesma forma, na área da Academia, o grande florescimento de escolas médicas por todo o país permite que os que tenham obtido a titulação universitária, como mestrado e doutorado tenham portas abertas no Mercado de trabalho fora dos grandes centros médicos, com remuneração melhor que o disponível no Mercado e a perspectiva de associar a universidade e carreira privada simultaneamente. 